\title{
Bovine trypanosomosis and its vectors: prevalence and control operations in Kellem Wollega, Western Ethiopia
}

\author{
Dereje Tsegaye $^{1}$, Getachew Terefe ${ }^{1}$, Deresse Delema ${ }^{3}$, and Abebayehu Tadesse ${ }^{1,2}$ \\ ${ }^{1}$ Addis Ababa University, College of Veterinary Medicine and Agriculture, Bishoftu, Ethiopia \\ ${ }^{2}$ Hawassa University, Faculty of Veterinary Medicine, Hawassa, Ethiopia \\ ${ }^{3}$ National Animal Health Diagnosis and Investigation Center, Sebeta \\ ${ }^{1}$ Corresponding Author: E-mail: abebayehutade20@gmail.com, P.O. B. 05, Hawassa, Ethiopia. \\ Mobile phone: $+251911389051 /+251989006784$
}

\begin{abstract}
A cross-sectional study was conducted to estimate the prevalence of bovine trypanosomosis and to assess farmers' perception of the disease and its control operations. From October to April 2012, a total of 586 cattle were sampled for the prevalence study. Buffy coat procedure and haematocrit value determination were performed. To capture the fly that was involved in the transmission dynamics, one hundred monopyramidal traps were deployed for 72 hours. A semi-structured questionnaire was conducted to study farmers' perceptions of the diseases and their control operations. Trypanosomal infections were diagnosed in only $8.7 \%$ (51) of animals. The overall prevalence of trypanosome infection in cattle was significantly varied between study districts (33.1\% Dale Sadi and $66.9 \%$ Dale Wabera). Most infections were due to Trypanosoma congolense (81.8\%) followed by T. vivax (15.6\%) and mixed infections (2.6\%). The association of hematological value changes and trypanosome infections was profound. The overall Packed Cell Volume (PCV) values of sampled cattle were $25.8 \%$. A significant $(P<0.05)$ variation in PCV values was recorded in infected (20.8\%) and non-infected (26.5\%) cattle. In the study period, a total of 2055 flies were captured and of which $92 \%$ belong to the genus Glossina followed by Stomoxys and Tabanids. Four types of tsetse species (G. pallidpes, G. m. morsitans, G. tachinoides, and G.f. fuscipes) were identified. The questionnaire survey revealed that trypanosomosis is the most important problem for agricultural activity and animal production in the study areas. Farmers are well aware of the problem, means of transmission, and the different control
\end{abstract}


methods. Integrating tsetse control program with other trypanosomosis control options is recommended.

Keywords: Bovine; Farmer's perception; Prevalence; Trypanosomosis; Vector.

\section{Introduction}

Tsetse transmitted trypanosomosis is one of the most devastating diseases of protozoan origin caused by different species of unicellular parasites found in the blood and other tissues of vertebrate hosts. The disease remains the main constraint to livestock production and agricultural development in humid and sub-humid zones of Africa (Swallow, 2000; Abebe, 2005). In Ethiopia, the disease affects a total of 14.8 million heads of cattle, an equivalent number of shoats, 7 million equines, and quite a considerable number of other domestic animals are at risk (Swallow, 2000; Abebe, 2005).

There are considerable variations on reports of the land cover of tsetse infested areas of Ethiopia since the first report appeared by an author (Langridge, 1976) nearly four decades ago where a total area was estimated as $98,000 \mathrm{~km}^{2}$. The Ministry of Agriculture had estimated the potential area of tsetse infestation to be about $220,000 \mathrm{~km}^{2}$ (MoARD, 2004). These areas are mainly found in the Southern, Southwestern, and Western parts of the country (Abebe and Jobre, 1996; Abebe, 2005). Many of the areas are the most suitable for livestock and crop production. However, they are virtually devoid of cattle and other domestic livestock (MOA, 1995; PATTEC, 2001; MoARD, 2004; Abebe, 2005). To date, five species of Glossina (G. m. submorsitans, G. pallidipes, G. tachinoides, G. f. fuscipes, and G. longipennis) have been recorded from Ethiopia. The tsetse flies transmit four species of trypanosomes: Trypanosoma congolense, $T$. vivax, T. brucei brucei, and T. rhodesiense (Abebe, 2005; Tadesse and Tsegaye, 2010).

Due to the presence of large fertile lands, the Dale Sadi and Dale Wabara districts of Kellem Wollega Zone in western Ethiopia comprise settlement areas for people from drought-stricken areas of the country. Most of the settlement areas are tsetse-infested which poses major constraints to livestock keepers to sustain in their new home areas. In the beginning, the settlement schemes have a history of heavy loss of cattle as a result of trypanosomosis mainly due to inadequate veterinary services and lack of tsetse control operations. As a 
result of the threat of tsetse flies, a large proportion of the livestock population of the settlement areas was exposed to trypanosomosis.

Although the impact of livestock trypanosomosis is a well-known constraint to livestock production in several tsetse infested areas of Ethiopia, little attention has been paid to the trypanosomosis situation in settlement areas of Birbir valley in western parts of the Oromia region. Furthermore, sufficient information was lacking on the status of the disease prevalence, tsetse fly challenge, and the attitude of farmers on tsetse and trypanosomosis intervention programs being practiced in the study districts. Understanding the epidemiology of the disease will facilitate the choice of suitable control methods and help in planning for development programs in the areas. Therefore, the study helps to estimate the prevalence of trypanosomosis situation, estimate the species composition and distribution of tsetse flies, the perception and knowledge of farmers on the diseases, management of the disease problems, tsetse fly challenge, and the impact of intervention practices in the study areas.

\section{Materials and methods}

\section{The study area}

The study was conducted in Dale Sadi and Dale Wabera districts of Kellem Wollega zone in Oromia regional state located in Birbir valley (Baro Akobo river system), western Ethiopia (Figure 1). The two districts are located 600$700 \mathrm{~km}$ West of Addis Ababa. The agro-climate of the areas alternates with long summer rainfall (June to September) and winter dry season (December to March), with annual rainfall ranging from 1300 to $1600 \mathrm{~mm}$. The mean minimum and maximum temperatures are $11.0-15.5^{\circ} \mathrm{C}$ and $26.1-34^{\circ} \mathrm{C}$ respectively. The altitude range for Dale Wabera is between 1100 and 1800 m.a.s.l. and that is 1400-2000 meter above sea level (m.a.s.l.) for Dale Sadi. The livelihood of the society largely depends on mixed livestock and crop production. The crops that are commonly cultivated include maize, sorghum, pepper, pulse, and finger millet. Coffee is the dominant one and is the main source of income for society. The dominant livestock population in both Dale Sadi and Dale Wabara districts in the Birbir valleys is cattle followed by goats and sheep where all of them are raised under the traditional management system. Other animals such as equines, poultry, and bees are also bred. In the livestock-crop mixed farming livelihood of the settlement schemes, cattle are used for drought power traction and milk production while sheep and goats, bees, and poultry are 
raised both for household consumption and income generation (KWZRADO, 2010).

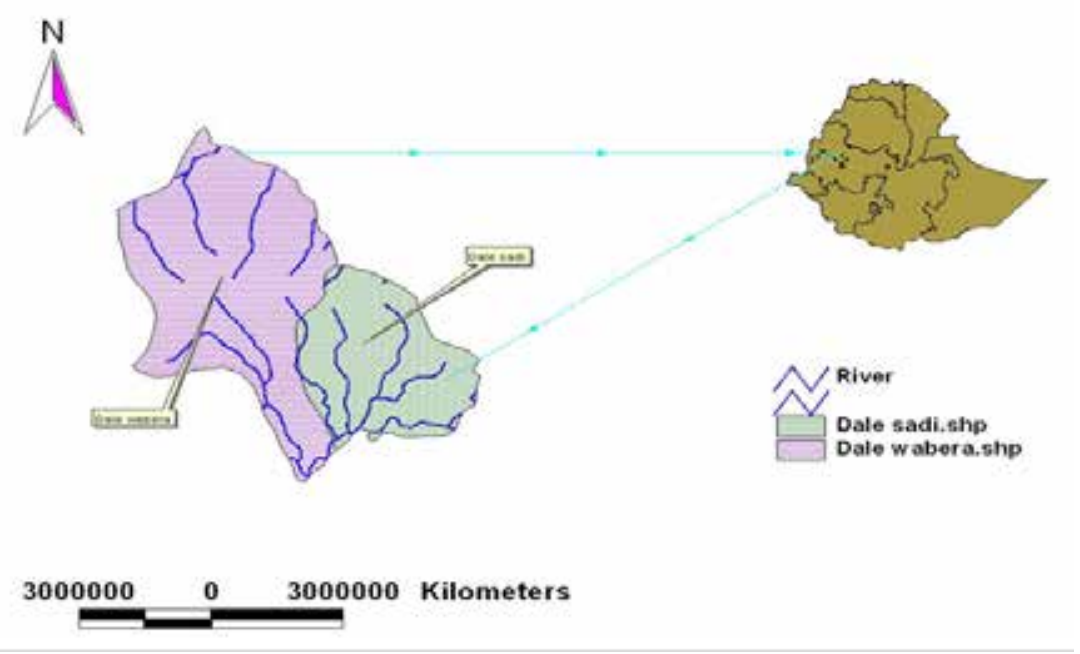

Figure 1. Map of Dale Wabera and Dale Sadi Districts

\section{Study animals}

From October to April 2012, a total of 586 cattle were sampled for the prevalence study Indigenous East African zebu cattle kept under traditional extensive husbandry systems with communal herding were used for blood sampling. Animals of all sex, age, and body condition groups were included. The animals were categorized into three age categories, calves ( $<1$ year) young (1-3 years), and animals that were able to move far distance away from homestead to graze were considered as adults (> 3 years).

\section{Sampling and sample size determination}

The sampling was based on combinations of multistage and purposive sampling methods applied according to Thrusfield (2005) and Toma et al. (1999). The two districts representing tsetse-infested settlement areas were selected from the Kellem Wollega zone in the Oromia region. Then within each district sampling frame was listed for every peasant association (PA) obtained from district agricultural offices and the PA were selected for sampling pur- 
posively based on accessibility and tsetse infestation. Announcements were made for farmers by local agricultural or animal health extension workers and community leaders to bring their cattle for examination. This was followed by systematic random selection of households that have brought their cattle for examination at specified locations among those registered on each sampling day. Similarly, among the cattle presented to the site for examination, animals were selected randomly. To determine sample size an expected prevalence of $50 \%$ (to increase the sample size) was taken into consideration and the desired sample size for the study was calculated using the formula given by Thrusfield (2005) at a 95\% precision level. Accordingly, the computed sample size was 384 animals. However, 589 animals were sampled to maximize the precision of the sample.

\section{Study design}

A cross-sectional study design was employed to estimate the prevalence, vector density and assess farmers' perception of the disease and its management.

\section{Parasitological and haematological examinations}

Blood samples were collected from marginal ear veins using microhematocrit capillary tubes and sealed on one side with cristaseal (Hawskely Ltd.). The capillary tubes were then transferred to a hematocrit centrifuge and spun for 5 min at 1200 revolutions per minute. Before processing the tubes for parasitological examination, measurement of packed cell volume (PCV) was made using a hematocrit reader (Murray et al., 1983). Then, the capillary tube was cut using a diamond-tipped pen 1 millimeter $(\mathrm{mm})$ below the Buffy coat to include the uppermost layers of the red blood cells and $3 \mathrm{~mm}$ above to include the plasma. The content of the capillary tube was expressed on the slide, homogenized onto a clean glass slide, and covered with a cover slide. The slide was examined under $\times 40$ objective using phase-contrast (Murray et al., 1977) or dark field microscopy (OMAX 40× 200× Binocular, Compound) to examine for the presence/absence of motile trypanosomes. For species identification of trypanosomes, Giemsa-stained thin blood film readings were made according to an established standard procedure to identify the different species of trypanosomes. 


\section{Entomological survey}

To assess the apparent densities, distributions, and species of tsetse flies and other biting flies, entomological data were collected along with the suitable tsetse habitats. These include livestock grazing areas, watering points, wild game reserve areas, rivers and riparian, savanna grassland, and sub-savanna area of dense riverside forests in the Districts. For the present entomological survey, standard monopyramidal traps developed for tsetse fly catch were used (Drees and Jackman, 1998). The traps were deployed at an interval of about 100-200 meters to assess the fly density. The coordinates of each trap position were recorded with a Global Positioning System (GPS). All the traps were baited uniformly with acetone and cow urine. The poles of traps were greased to prevent fly predators mainly ants. A total of 100 traps were deployed early in the morning and maintained in position for $48 \mathrm{hrs}$ in trapping sites. The cages from these traps were emptied and caught flies were counted, identified morphologically, and sexed for the tsetse fly (Walle and Shearer, 1997).

\section{Questionnaire survey}

A semi-structured questionnaire survey was conducted on 105 selected farmers (56 farmers from Dale Wabera and 49 from Dale Sadi district). Community elders and key informants like local PA administrators and agricultural extension workers were involved in the study. They helped in the identification of households within the area that kept livestock. Those farmers that possess cattle are only interviewed. The interviews were conducted in Oromifa and Amharic languages. Mostly the questions are the open-ended type with a limited number of questions having a list of choices. Before the interview, the objective of the research was explained to each participant and full consent of the interviewers was obtained. The questionnaire focused mainly on general livestock production, perception of the presence and management of trypanosomosis in cattle, and impact of tsetse and trypanosomosis control efforts in the area.

\section{Data management and analysis}

Data collected were entered into MS Excel to create a database. The edited data were then transferred to the statistical software program called SPSS versions 20 for windows. Descriptive statistics, univariable and multivariable logistic regression, confidence intervals, and analysis of variance were applied in the analysis of the data. The prevalence of bovine trypanosomosis was expressed as the number of parasitaemic animals through buffy coat microscopy 
to the total number of animals examined (Murray et al., 1983). Hematological findings were expressed as a percentage of the RBC to the total blood content in percentage as measured by hematocrit reader. To compare trypanosomosis prevalence and the pooled data of mean PCV between aparasitaemic and parasitaemic animals a combination of frequency distribution and independent $t$ test were used. A logistic regression model was used to test the association and the odds for the degree of severity between the prevalence of trypanosome and the assumed risk factors. The apparent fly density was calculated as the mean number of tsetse and biting flies caught per trap per day. In all cases, a $95 \%$ CI was employed to extrapolate sample results to the target population in the study area to assess the dynamics of trypanosomosis and the vectors.

\section{Results}

\section{Prevalence of trypanosomosis}

A total of 589 blood samples were examined from cattle in settlement schemes of the study districts (Table1).

Table 1. The geographical locations of sampling sites (PA's) within the two districts used for sample collection and the respective number of samples collected

\begin{tabular}{|c|c|c|c|c|c|c|}
\hline Zone & Districts & $\begin{array}{l}\text { Sampling } \\
\text { PA }\end{array}$ & $\begin{array}{l}\text { Number } \\
\text { of } \\
\text { samples }\end{array}$ & $\begin{array}{l}\text { Altitude } \\
\text { (m.a.s.l.) }\end{array}$ & Latitude & Longitude \\
\hline \multirow{2}{*}{$\begin{array}{l}\text { Kellem } \\
\text { Wollega }\end{array}$} & Dale Sadi & Bikilabirbir & 101 & 1409 & N84 $4^{0} 75^{\prime} 23$ & $\mathrm{E} 35^{0} 111^{\prime} 20$ \\
\hline & & Village 14 & 94 & 1477 & $\mathrm{~N} 84^{\circ} 84^{\prime} 46$ & $\mathrm{E}^{2} 5^{0} 112^{\prime} 08$ \\
\hline \multirow[t]{5}{*}{ Subtotal } & & & 195 & & & \\
\hline & $\begin{array}{l}\text { Dale } \\
\text { Wabara }\end{array}$ & Midega & 71 & 1175 & $\mathrm{~N} 84^{0} 14^{\prime} 11$ & $\mathrm{E}^{\circ} 5^{\circ} 07^{\prime} 18$ \\
\hline & & Village 8 & 145 & 1172 & N85 $417^{\prime} 93$ & $\mathrm{E}^{2} 35^{\circ} 051^{\prime} 90$ \\
\hline & & Kombo & 100 & 1537 & $\mathrm{~N} 85^{\circ} 07^{\prime} 79$ & $\mathrm{E}^{2} 5^{\circ} 066^{\prime} 53$ \\
\hline & & Chirecha & 78 & 1528 & $\mathrm{~N} 85^{0} 17^{\prime} 78$ & E35 $072^{\prime} 89$ \\
\hline Subtotal & & & 394 & & & \\
\hline
\end{tabular}

Trypanosomal infections were only diagnosed in 51 (8.7\%) animals. The difference in the overall prevalence of trypanosomosis between the two districts was 
significant $(P<0.05)$. Most infections were due to $T$. congolense followed by $T$. vivax and mixed infections (2.6\%) (Table 2).

Table 2. The prevalence of trypanosomes against the risk factors assumed

\begin{tabular}{|c|c|c|c|c|c|c|c|}
\hline Risk factors & No. examined & Positive & negative & \% Positive & $\% \mathrm{Tc}$ & $\% \mathrm{Tv}$ & \% Mixed \\
\hline \multicolumn{8}{|l|}{ Districts } \\
\hline Dale Sadi & 195 & 13 & 182 & 6.7 & 84.6 & 15.4 & 0 \\
\hline Dale Wabara & 394 & 29 & 365 & 8.7 & 78.9 & 15.8 & 5.3 \\
\hline \multicolumn{8}{|l|}{ PA's } \\
\hline Bikilabirbir & 101 & 12 & 79 & 28.6 & 19.6 & 5.8 & 0 \\
\hline Village14 & 94 & 1 & 93 & 2.4 & 2 & 0 & 0 \\
\hline Midega & 71 & 8 & 61 & 19.1 & 29.4 & 0 & 0 \\
\hline Village8 & 145 & 17 & 138 & 40.5 & 25.5 & 7.4 & 0 \\
\hline Kombo & 100 & 3 & 97 & 7.1 & 2 & 2 & 3.9 \\
\hline Chirecha & 78 & 1 & 77 & 2.4 & 2 & 0 & 0 \\
\hline \multicolumn{8}{|l|}{ Age } \\
\hline$\leq 3$ & 173 & 16 & 157 & 9.25 & 62.5 & 37.5 & 0 \\
\hline$>3$ & 416 & 35 & 381 & 8.4 & 91.4 & 5.7 & 2.9 \\
\hline \multicolumn{8}{|l|}{ Sex } \\
\hline male & 338 & 39 & 299 & 11.54 & 84.6 & 15.4 & 0 \\
\hline female & 251 & 12 & 239 & 4.78 & 75 & 16.7 & 8.3 \\
\hline \multicolumn{8}{|l|}{ BCS } \\
\hline good & 143 & 9 & 134 & 6.3 & 100 & 0 & 0 \\
\hline medium & 366 & 30 & 336 & 8.2 & 80 & 16.7 & 3.3 \\
\hline poor & 80 & 12 & 68 & 15 & 75 & 25 & 0 \\
\hline
\end{tabular}

PA= Peasant Association

The risk of infection in the higher altitude was relatively lower than that of lower altitude where $T$. congolense had shown a statistically significant difference $(P<0.05)$. The prevalence in males $(11.54 \%)$ was relatively higher than that of the female animals $(4.78 \%)$ and the difference was significant $(P<0.05)$. The poor $(15 \%)$ body conditioned animals were shown significant $(P<0.05)$ variation in trypanosome prevalence with reference to good (6.3\%) and medium body conditioned cattle (8.2\%) (Table 3$)$. 
Table 3. The logistic regression output of the overall prevalence of bovine trypanosomosis in different factors considered

\begin{tabular}{|c|c|c|c|c|c|c|}
\hline \multirow{2}{*}{$\begin{array}{l}\text { Factors } \\
\text { districts }\end{array}$} & \multirow{2}{*}{$\begin{array}{l}\begin{array}{l}\text { Odds } \\
\text { Ratio }\end{array} \\
0.11\end{array}$} & \multirow{2}{*}{$\begin{array}{l}\text { Std. Err. } \\
0.12\end{array}$} & \multirow{2}{*}{$\begin{array}{l}\mathbf{z} \\
-2.07\end{array}$} & \multirow{2}{*}{$\begin{array}{l}\mathbf{P}>|\mathbf{z}| \\
0.038\end{array}$} & \multicolumn{2}{|c|}{ [95\% Conf. Interval] } \\
\hline & & & & & {$[0.01$,} & $0.89]$ \\
\hline \multicolumn{7}{|l|}{ PA's } \\
\hline Village14 & 0.07 & .077412 & 2.47 & 0.014 & {$[0.01$} & $0.58]$ \\
\hline Midega & 6.37 & 6.934121 & 1.70 & 0.089 & {$[0.75$} & $53.8]$ \\
\hline Village8 & 7.30 & 7.670551 & 1.89 & 0.059 & {$[0.93$} & $57.2]$ \\
\hline Kombo & 1.72 & 2.013836 & 0.46 & 0.644 & {$[0.17$} & $17.1]$ \\
\hline Chirecha & (omitted) & & & & & \\
\hline Sex & 0.39 & 0.1559274 & -2.36 & 0.018 & {$[0.18$} & $.85]$ \\
\hline Age & 1.04 & .4153521 & 0.11 & 0.915 & {$[0.48$} & $2.28]$ \\
\hline \multicolumn{7}{|c|}{ Body condition } \\
\hline Medium & 1.97 & .9018469 & 1.48 & 0.139 & {$[0.80$} & $4.83]$ \\
\hline Poor & 3.92 & 2.094172 & 2.55 & 0.011 & {$[1.37$} & 11.17] \\
\hline
\end{tabular}

\section{Hematological findings}

The study revealed that the PCV values of cattle were generally low in both districts (Fig1). However, there was a significant difference in the mean PCV of the two districts (Dale Sadi, 26.5\% CI=26-27.1\%) Dale Wabara (20.0\% CI= 18.0- 22.5\%). The PCV of animals within the normal range (PCV $\geq 24)$ was significantly higher $(27.6 \%, 95 \% \mathrm{CI}=27.4-28.0 \%)$ than those with lower PCV $(\mathrm{PCV}<24)(19.8 \%, \mathrm{CI}=19.4-20.2 \%)($ Table 4$)$.

The PCV of cattle was $20.8 \%(95 \% \mathrm{CI}=19.5-22.1 \%)$ for infected animals and $26.0 \%$ (CI=25.6- 26.3\%) for non infected animals. The difference between the means of the two groups was $5.2 \%$ and it was statistically significant (Table 4). 
Table 4. The result for PCV in infected and noninfected animals and districts

\begin{tabular}{|c|c|c|c|c|c|c|c|c|}
\hline \multirow{2}{*}{$\frac{\mathbf{P C V}}{\text { Noninfected }}$} & & \multirow{2}{*}{$\begin{array}{l}\text { Obs } \\
538\end{array}$} & \multirow{2}{*}{$\begin{array}{l}\text { Mean (\%) } \\
26.0\end{array}$} & \multirow{2}{*}{$\frac{\text { SE }}{0.18}$} & \multirow{2}{*}{$\frac{\text { SD }}{4.2}$} & \multicolumn{2}{|c|}{$[95 \% \mathrm{CI}]$} & \multirow{2}{*}{$\begin{array}{l}P \text { value } \\
\leq 0.0001\end{array}$} \\
\hline & & & & & & {$[25.6$} & 26.3] & \\
\hline infected & & 51 & 20.8 & 0.64 & 4.6 & {$[19.5$} & 22.1] & \\
\hline PCV status & $\mathrm{PCV} \geq 24$ & 430 & 27.7 & 0.14 & 2.9 & {$[27.4$} & 27.9] & $\leq 0.0001$ \\
\hline \multirow{3}{*}{ District } & $\mathrm{PCV}<24$ & 159 & 19.8 & 0.20 & 2.5 & {$[19.4$} & $20.2]$ & \\
\hline & Dale Sadi & 195 & 26.5 & 0.29 & 4.0 & {$[26.0$} & 27.1] & 0.0001 \\
\hline & Dale Wabara & 394 & 25.0 & 0.23 & 4.6 & {$[24.6$} & $25.5]$ & \\
\hline
\end{tabular}

\section{Entomological survey}

A total of 2055 flies were caught using 100 monopyramidal traps deployed at different sites of the study areas. Out of which 1890 (92 \%) belongs to tsetse flies of the genus Glossina (tsetse fly) followed by Stomoxs 159 (7.7\%) and Tabanids 6 (0.3 \%). Four tsetse species were identified (G. pallidpes, G. m. morsitans, G. tachinoides, and G. f. fuscipes). The overall apparent density of tsetse flies was $18.9 \mathrm{~F} / \mathrm{D} / \mathrm{T}$. Of which $9.1 \mathrm{~F} / \mathrm{D} / \mathrm{T}$ was from Dale Wabera and 9.8 F/D/T was from Dale Sadi.

The apparent density of tsetse flies in Dale Wabera was: G. pallidpes $1.8 \mathrm{fly} /$ trap/day, G. m. morsitans 0.9 fly/trap/day, G. tachinoides 0.9 , and G. f. fuscipes $1.6 \mathrm{fly} /$ trap/day whereas the apparent density of tsetse flies in Dale Sadi district was G. pallidipes 5.9 fly/trap/day/ G. m. morsitans 6.2 fly/trap/day, G. tachinoides 0.8 fly/trap/day and G. f. fuscipes 1.1 fly/trap/day. Generally, Savanna species appear to be dominant in both districts. Altitude had a significant effect on the apparent density of tsetse in the Dale Wabera district which is found relatively in higher altitudes. The survey revealed that $93.3 \%$ of the total fly catch was from a low altitude whereas, $6.7 \%$ of the total catch is from a higher altitude. There was a significant difference for $T$. congolense prevalence between the low altitude (1172-1190 masl) and higher altitude areas (14311488 masl) $(P<0.05)$. However, this was not the case for T. vivax (Table 5). 
Table 5. The apparent density and tribes of flies caught during the study period

\begin{tabular}{|c|c|c|c|c|c|c|c|c|c|c|c|c|c|c|}
\hline \multirow{3}{*}{$\begin{array}{l}\text { Trap } \\
\text { type }\end{array}$} & \multirow{3}{*}{$\begin{array}{l}\text { Altitude } \\
\text { (m.a.s.l) }\end{array}$} & \multirow[t]{3}{*}{ Site } & \multicolumn{8}{|c|}{ Tsetse flies } & \multirow{3}{*}{$\begin{array}{l}\text { Sto } \\
\text { moxys }\end{array}$} & \multirow{3}{*}{$\begin{array}{l}\text { Taba } \\
\text { nus }\end{array}$} & \multirow{3}{*}{$\begin{array}{l}\text { haem } \\
\text { atop } \\
\text { ota }\end{array}$} & \multirow[t]{3}{*}{ FTD } \\
\hline & & & \multicolumn{2}{|c|}{$\begin{array}{l}\text { G.m. } \\
\text { submor } \\
\text { sitans }\end{array}$} & \multicolumn{2}{|c|}{$\begin{array}{l}\text { G. palli } \\
\text { dipes }\end{array}$} & \multicolumn{2}{|c|}{$\begin{array}{l}\text { G. } \\
\text { tachin } \\
\text { oides }\end{array}$} & \multicolumn{2}{|c|}{$\begin{array}{l}\text { G. fusc } \\
\text { ipes }\end{array}$} & & & & \\
\hline & & & M & $\mathrm{F}$ & M & F & M & $\mathrm{F}$ & M & $\mathrm{F}$ & & & & \\
\hline $\begin{array}{l}\text { Monopyr } \\
\text { amidal }\end{array}$ & 1293 & D. sadi & 190 & 155 & 145 & 185 & 22 & 23 & 34 & 26 & 53 & 0 & 0 & 28 \\
\hline $\begin{array}{l}\text { Monopyr } \\
\text { amidal }\end{array}$ & 1393 & $\begin{array}{l}\text { D. Wab } \\
\text { ara }\end{array}$ & 61 & 68 & 68 & 195 & 58 & 74 & 95 & 130 & 239 & 6 & 2 & 9 \\
\hline
\end{tabular}

\section{Questionnaire survey}

\section{Livestock use and management}

Cattle, sheep, goats, and equines are common livestock species kept by farmers in the study districts. All of the interviewed people were well responded to the prepared questionnaire format. The majority of the resident communities of the two districts have lived in the area for more than five years (Figure 2) and were able to describe the animal disease situation of the districts effectively.

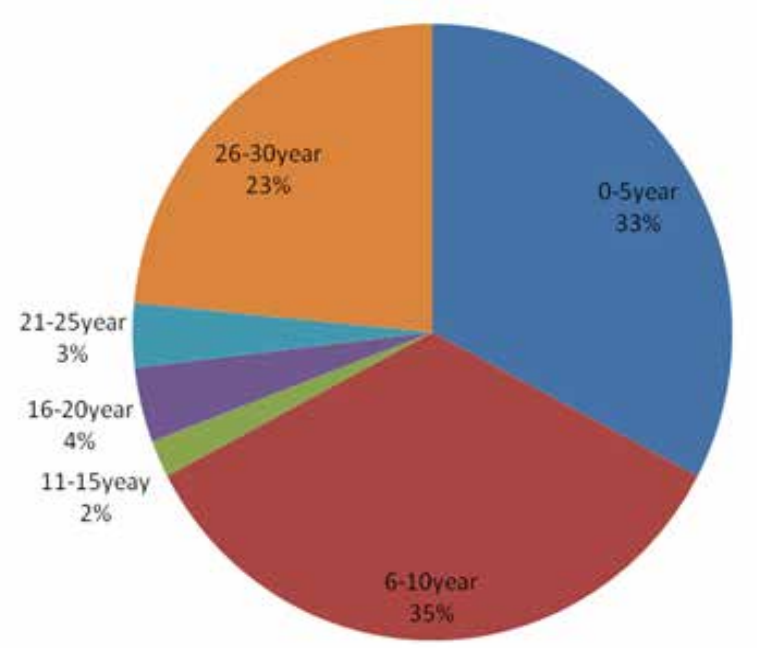

Figure 2. The percentage of farmers describing the time of starting farm activities in the study area 
The farmers in the area ascertained that they keep livestock mainly for agricultural activities. Accordingly, above $99 \%$ of the respondents' livelihood depends on a mixed crop-livestock production system. The most common livestock species kept in the area based on interview response are cattle (53.3\%) followed by cattle and small ruminants (34.3\%) and others (12.4\%). Most farmers kept the animals mainly for drought power and milk (Table 6). According to the respondents, livestock feed shortage would have been observed during the dry season when almost the grazing land is overgrazed. Better feed is available during the late and early rainy season (July-September) when the pasture is green and the feed biomass is relatively high. The main constraint of livestock in the area as mentioned by $100 \%$ of the respondents were animal diseases but the shortage of grazing land and less availability of veterinary drugs were also mentioned.

Table 6. The purpose of animal breeding in the study area

\begin{tabular}{lcc}
\hline Purpose of breeding & frequency & \% \\
\hline Drought power & 38 & 36.2 \\
Milk & 3 & 2.9 \\
Milk and drought power & 62 & 59.1 \\
Fattening & 1 & 0.95 \\
Fattening and drought power & 1 & 0.95 \\
\hline
\end{tabular}

\section{Constraints of livestock production in the study areas}

Based on the interview result, the main livestock diseases in the order of importance are trypanosomosis, pasteurellosis, ectoparasites, blackleg, lumpy skin disease, and anthrax as shown in Figure 3 below. 


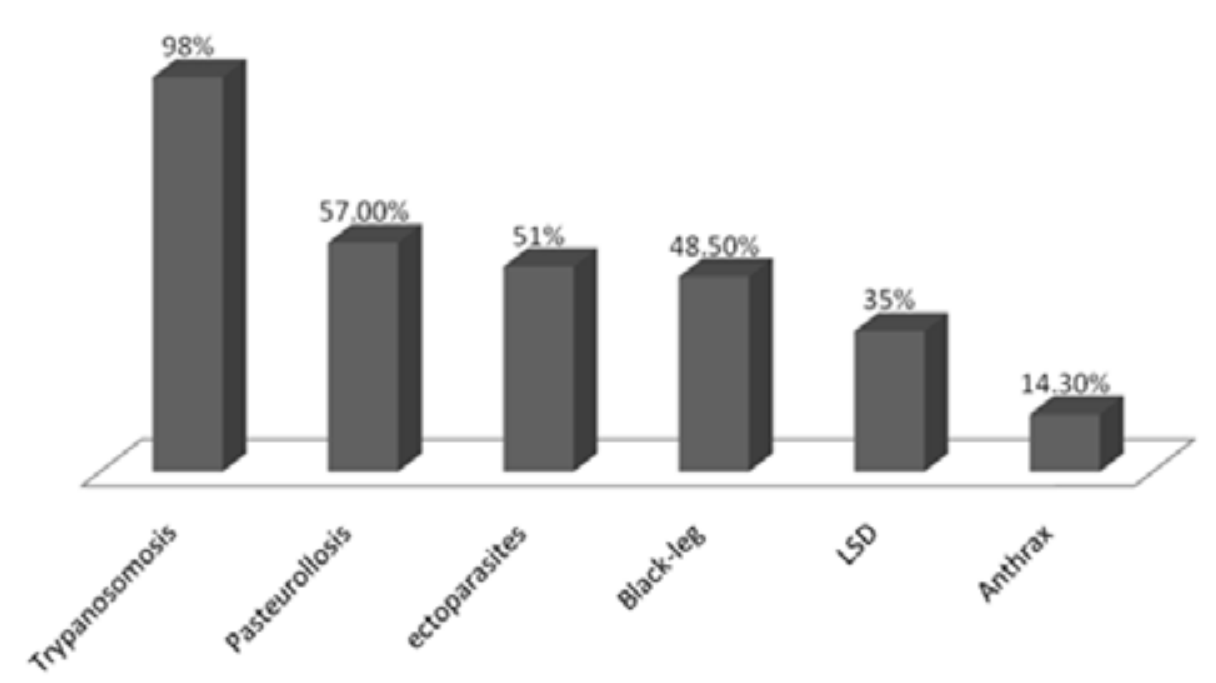

Figure 3. Diseases in the area in the order of their importance

All the respondents think that trypanosomosis is a major constraint and serious threat to livestock production and utilization of the fertile arable land. It is known by all locally as "Ghendi" and mostly affects cattle (100\% responders). Clinical signs observed by the farmers: emaciation, ruffle hair coat, constipation, change in color coat, lack of appetite, necrosis and cut-off tail, weakness, eating soil, dry feces, grinding of teeth, and finally death. Most farmers (91.4\%) said that the incidence of disease (trypanosomosis) is high in the rainy season but infection occurs throughout the year. Out of the 105 interviewed farmers, $14.4 \%, 48.6$ and $29.5 \%$ of respondents know the disease for the last 5 years, last 10 years, and last 15-20 years respectively. Almost all (99\%) of them also affirmed that the situation of the disease is now improving as described by the reduction of its impacts on livestock.

\section{Means of transmission}

Out of the 105 respondents, 97\% of them knew flies as transmitters of trypanosomosis to their cattle (Table 2). When asked to specify the fly type, they call it "ghendi zinb/Tisisa ghandi) and described it as having long legs, large size, brown color biting their animals when the animals move to the forest and savanna vegetation types their equivalent might be tsetse fly other flies bigger in size, cause bleeding at the point of bite locally call as "Warana" their equiva- 
lent are tabanids and stomoxyes flies. Most believe that the fly population is higher in the rainy (58.1\%) and following after the rainy (41.9\%) season. All respondents believe that fly density was high around water bodies and valleys.

Table 7. Respondent's perception of the source of trypanosomosis

\begin{tabular}{lcc}
\hline Source & No of respondents & $\%$ \\
\hline Tsetse flies & 102 & 97.14 \\
Infected grass and water & 1 & 0.95 \\
Others & 2 & 1.91 \\
\hline
\end{tabular}

\section{Trypanosomosis and vector control}

All respondents acknowledged that tsetse and trypanosomosis control operations have been there for a long time. They (88.6\%) also added that control of trypanosomosis is carried out mainly through a combination of treatment of affected animals with trypanocidal drugs and tsetse flies population control in the area. Only $7.6 \%$ and $3.8 \%$ of them believe that fly control alone and chemotherapy alone was the control option available respectively.

About $88 \%$ of respondents get trypanocidal drugs from government veterinary clinics, while others obtain the drugs from private clinics (8.6\%) and illegal sources (3.8\%). Most of the farmers (88.6\%) send their animals to veterinary clinics and treat them by animal health personnel while $11.4 \%$ of them responded to treat by themselves/family members at home. Diminazene aceturate (Berlin) and Isometamidium chloride (Samorin) are the commonly used drugs to treat trypanosomosis (Figure 4). Information gathered from the respondent farmers and animal health personnel emphasized it is a common practice to monthly send animals to animal health posts for trypanocidal treatment irrespective of the presence or absence of disease and this trend is locally called "Worawi" (monthly) in the community. 


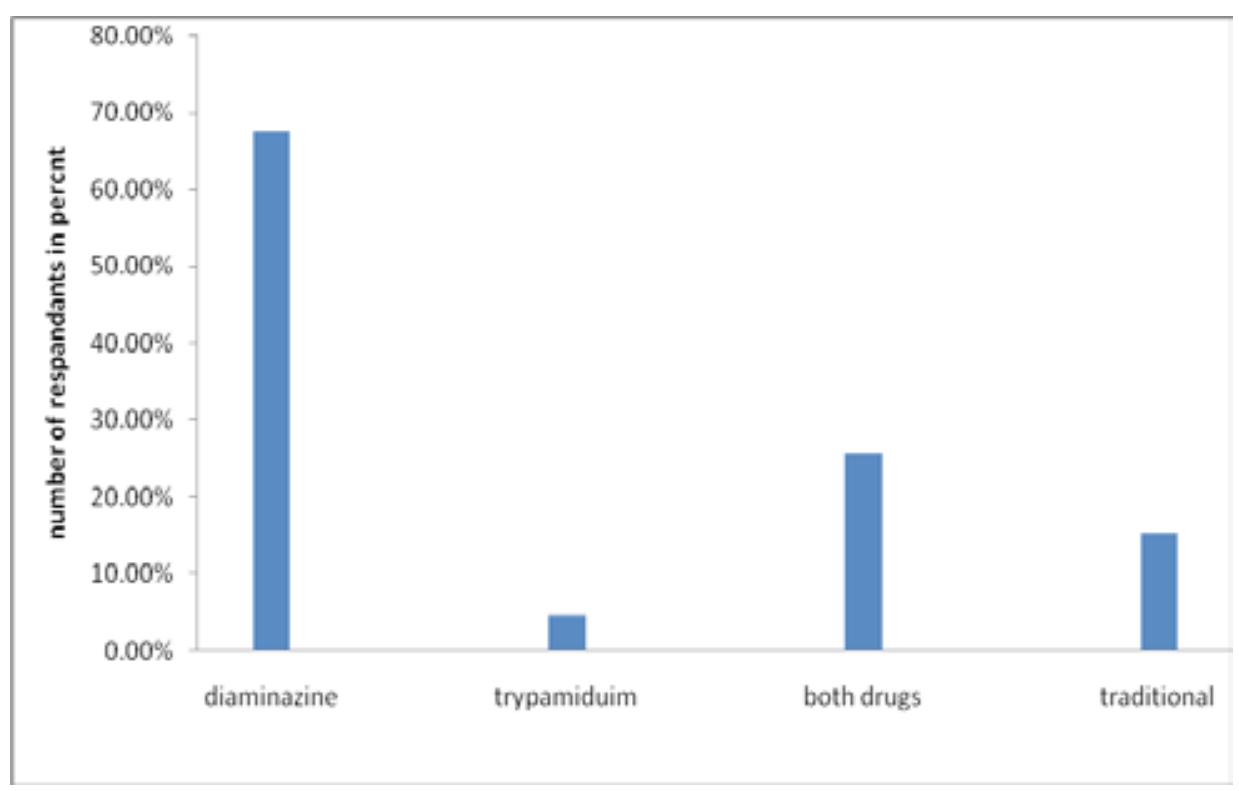

Figure 4. Most common trypanocidal drugs farmers used to treat their animals.

As the respondents mentioned, the National Tsetse and Trypanosomosis Investigation and Control Center (NTTICC, 1996) has been conducting surveillance, updating distribution maps, undertaking trypanocidal drugs sensitivity tests, and implementing control schemes through the integration of pour-on with odor baited and insecticide-impregnated target technologies for the last few years in the study area. All the interviewed farmers also indicated that this control program is the most essential and it brings good results in their area in terms of fly population reduction and the activity is participatory (training of community on target deployment technique, about the impact of drug resistance and the vectors of the disease, etc.). As information revealed by farmers, all techniques employed for the control program are requiring their participation so that, about $99 \%$ of respondents said that they have been actively participating in the deploying target in site, extensively training and giving information to others farmers and supporting the technicians accordingly. After the launching of the control program, 99\% of the farmers said that the incidence of the disease is getting better compared with previous periods. They describe the changes in terms of an increasing number of their animals, increasing working efficiency, increasing milk yield, reduction in the cost of treatment, increasing 
selling prices, improvement of animal body condition, and decreasing mortality rate. The changes in the livestock health were so significant that all respondent farmers of the two woredas they want to continue and enhance their active participation in the control of tsetse and trypanosomosis by volunteering money and labor and protection of properties (traps, targets, etc. in the field against theft and fire) to ensure the sustainability of the program.

\section{Discussion}

The study revealed the presence of bovine trypanosomosis in the settlement schemes of the Biribir valley. This has shown a $7.1 \%$ overall prevalence of trypanosomosis and dominance of $T$. congolense (81.8\%) over T. vivax (15.6\%). The result was relatively lower than the previous report (8.5\%) of Senbata (2010) in Southwestern Ethiopia but higher than the reports (2.4\%) of Tadesse and Tsegaye (2010) in Western Ethiopia. However, it was lower in contrast to the reports of other authors elsewhere in tsetse infested areas of the country (Rowlands et al., 1995; Abebe and Jobre, 1996; Yohannes et al., 2000; Tefera, 2008; Bekele et al., 2010; Biyazen et al., 2014). Accordingly, Terefa (2008) and Bekele et al. (2010) reported a prevalence of $15.1 \%$ and $21 \%$ in tsetse-infested Western and Southern Rift valley areas, respectively. Similarly, a higher prevalence of $17.2 \%$ and $17.5 \%$ were reported in tsetse-infested Metekel and upper Didessa areas (Yohannes et al., 2000).

This study has clearly shown the relatively lower prevalence of trypanosomosis in the settlement schemes in contrast to the findings of other tsetseinfested areas. This disparity emanates from many factors that explain the lower prevalence of trypanosomosis observed in this study area. The study was conducted during the early dry period and this might have affected the vector population and subsequently the trypanosome prevalence (Leak et al., 1993). Furthermore, the expansion of veterinary services up to peasant association, deforestation for crop cultivation (settlement), frequent usage of trypanocidal drugs and the husbandry practices on animals, and presence of trypanosomosis and fly control program in the area might have contributed positively to the observed lower prevalence.

This finding of the trypanosome species is in accordance with the reports of other authors (Rowlands et al., 1995; Abebe and Jobre, 1996; Yohannes et al., 2000; Tewelde, 2001; Tefera, 2008; Bekele et al., 2010; Tadese and Tsegaye, 
2010). This is in general agreement about T. congolense as the dominant trypanosome species in tsetse-infested regions of Ethiopia. Abebayehu and Biniam (2010) from Southwestern Ethiopia and Bekele et al. (2010) from the Southern rift valley reported T. congolense as dominant species. They reported $36.4 \%$ and $70 \%$ T. congolense and $18.2 \%$ and $20 \%$ T. vivax infection, respectively. In contrary to the prevalence of $T$. congolense in tsetse-infested areas of Ethiopia, T. vivax is the only species with a major health problem to cattle in non-tsetse-infested areas of Ethiopia (Cherinet et al., 2006; Misganaw, 2006; Sinshaw et al., 2006).

The predominance of $T$. congolense infection in cattle of tsetse-infested areas may be due to the high tendency of the parasite to develop new strains capable of escaping the host immune response. The host has the potential to the development of better immune response against $T$. vivax compared to $T$. congolense infections (Leak, 1999). In the present study mixed infection is not significant in contrast to the reports from other areas but that does not mean to rule out its importance.

The overall prevalence of trypanosomosis between the districts was significant $(P<0.05)$ where the disease is $11 \%$ more likely to occur in Dale Wabara than in Dale Sadi. The study involved four PAs from Dale Wabara and two from Dale Sadi with relatively higher prevalence being reported in Village 8 (40.8\%) and the lowest being in Village $14(2.4 \%)$ and Chirecha (2.4\%). Village 8 is the lowland area with an altitude of 1172 m.a.s.l while Village 14 and Chirecha PAs are found relatively at higher altitudes with 1477 and 1528 m.a.s.l. respectively. Altitude difference has been identified as one of the main factors for variation in trypanosome prevalence. This variation between districts and villages in the study could be attributed to the presence of suitable habitat for the vectors which results in high fly density. Variation in tsetse density appeared to be the main factor for variation in the prevalence of trypanosomosis. The tsetse and other biting fly populations and types present in each locality, which are dependent on microclimate, animal herd density, the distance between herds, and other various factors (Leak et al., 1993).

Although the relatively lower prevalence was recorded in adults (8.4\%) than the young animals $(9.3 \%)$, the infection with trypanosomes seems unrelated to the age of the animals $(P>0.05)$. On the contrary, other reports show that trypanosomosis is a chronic disease increase with the age of animals and its infection is usually higher in adult than in young animals (Rowlands et al., 
1993; Rowlands et al., 1995; McDermott et al., 2003; ). Similarly, the attraction of tsetse flies more by the odor of older animals has been reported (Torr, 1995; Torr and Mangwiro, 2000; Torr et al., 2006).

The prevalence in males (11.54\%) was higher than the females $(4.78 \%)$ and the difference was significant $(P>0.05)$. Different authors were also reported a higher infection rate in male animals than females (Muturi, 1999; Yohannes et al., 2000; Tewelde, 2001) and the possible suggestion could be the use of males more for drought purposes traveling long distances to an area of tsetse challenge for grazing and its use in plough as draft power which causes stress so the animal becomes susceptible to trypanosomosis.

Trypanosomosis is a disease that is usually associated with poor body condition and emaciation. In the present study, animals with poor body conditions were more associated with the disease as compared with animals with medium and good body conditions and the difference was significant $(P<0.05)$. However, it does not mean that trypanosomosis is necessarily associated with poor body condition or emaciation. Other factors such as helminthiasis and feed shortage may be implicated as the cause of the deterioration of the condition (Parkins and Holmes, 1989).

The trypanosome-infected cattle were shown profound changes in hematological values of infected animals. The overall PCV value of cattle was $25.8 \%$. Of which $20.8 \%$ was due to the presence of trypanosomes infection. The difference in PCV of infected and noninfected animals was significant $(P<0.05)$. However, a considerable number of animals $(76.7 \%)$ were anemic $(\mathrm{PCV}<24 \%)$ without having trypanosomes infection. Some animals $(2.5 \%)$ were positive to trypanosomosis but their PCV was normal ( $\mathrm{PCV} \geq 24 \%$ ). This may suggest the presence of other anemia-causing factors and on the other hand individual variability in the maintenance of normal PCV in infected animals. Trypanosomosis is also known to causes a reduction in weight gain and productivity (Rowlands et al., 2001). However, the difference in mean PCV value between infected and noninfected animals indicates that trypanosomosis reduces the PCV values in infected animals (Bekele et al., 2010).

The damage of tissue due to trypanosomosis is probably multifactorial in etiology, but the underlying feature is progressive anemia throughout the course of the disease. The case of anemia is due to hemolysis caused primarily by erythrophagocytosis due to simulation and expansion of the mononuclear phago- 
cytosis system (Seifert, 1996). Taylor (1998) indicated that anemia persists during the chronic stages of infection when parasitaemia is generally quite low, probably because different mechanisms are involved in its genesis during the acute and chronic stages of infection. This suggests that control of parasitaemia and control of anemia is unrelated in the chronic phase when immune infections are depressed and anemia is sustained through dyserythropoiesis.

Monopyramidal trap was the only trap type used from a variety of traps that have been designed to catch different species of tsetse and other biting flies because of its availability. The apparent density of tsetse flies was about 18.9 flies per trap per day. A total of 2055 flies were caught of which $92 \%$ belong to the genus Glossina (tsetse flies) the followed by Stomoxs and Tabanids. Four types of tsetse species (G. pallidpes, G. m. morsitans, G. tachinoides, and G. f. fuscipes) have been identified. The apparent density of tsetse flies recorded significantly differed between the two districts. Similarly, other researches support the present finding from the Gawo District of West Oromia (Terefa, 2008). However, Senbata (2010) has reported higher tsetse density from the same study area and Hawa Gelan Districts. In contrast to the present finding, Tadesse and Tsegaye (2010) reported lower apparent densities of tsetse flies in Southwestern Ethiopia.

The density of tsetse flies within and between districts might be affected by the number of traps deployed, the site of trap deployment, and the months of the study period. Moreover, the density is affected by the favorable environment such as enough moisture, vegetation growth, and suitable habitat. The fly species identified also agrees with the reports of Terefa (2008) and Senbata (2010). G. pallidipes covered a vast area with high apparent densities. This could be because this species inhabits a wide range of vegetation types that are available in the area. While $G$. m. morsitans was found to be almost restricted to savannah vegetation and thus its distribution is highly dependent on the season and vegetation coverage (IAEA, 2004).

G. f. fuscipes and G. tachnoides were distributed along the large river of Birbir and its tributaries like Keto, Chabal, Hindina, Kile, and others, which cross the study areas and thus provide a conducive environment. The sex ratio of flies was biased towards females. This is in agreement with the report of other authors (Mohamed-Ahmed et al., 1989; Msangi 1999; Leak 1999) where female flies comprise $70-80 \%$ of the mean tsetse fly population. 
The result of the questionnaire survey revealed that trypanosomosis is the most important problem for agricultural activity and animal production in the study areas. Above 99\% of farmers' livelihood depends on a mixed crop-livestock farming system. The majority of livestock reared in the area were cattle followed by small ruminants and equines. The livestock disease, shortage of grazing land, and scarcity of modern veterinary services were the challenges for the development of the area. Several other works demonstrated the same constraints elsewhere in Ethiopia (Dangnachew et al., 2005).

The disease trypanosomosis was reported to be the most and the first important livestock constraint limiting the overall agricultural activity and livestock productivity by almost $100 \%$ of interviewed people. Similar findings were reported by Tewelde (2001) and Yohannes et al. (2000). The incidence of the disease reaches its peak during and after rainy seasons while the infection is persistent throughout the year in the current study area. However, Yohannes et al. (2000) in Metekel and Tewelde (2001) in west Ethiopia reported that the incidence of trypanosomosis was high throughout the year.

Farmers acknowledged that tsetse and trypanosomosis control program is present in their area and the activity is participatory. They also added that the situation is improving since the introduction of the intervention program through fly control by pour-on insecticide spray and fly trapping. Observations in other areas indicated that tsetse fly control schemes around Arbaminch Zuria have significantly reduced the prevalence of trypanosomosis and fly density followed by a reduction in calf mortality (Gechere et al., 2012). However, due to the long history of the disease in the area, they developed the habit of frequently treating their animals with chemotherapeutics such as Diminazine aceturate and Isometamidium chloride. A similar finding was reported about the drugs used by previous researchers in many parts of the country (Yohannes et al., 2000; Seyoum et al., 2013). According to Van den Bossche et $a l$. (2000), the majority of farmers prefer to use Diminazine aceturate than Isometamidium chloride. The study also supported this conclusion in that majority of the respondents affirmed that they use Diminazine may be due to its fast curative response. While the observation that the majority of the respondents use veterinary services for their source of trypanocidal drugs and injections is encouraging, a proportion of them are still using drugs from illegal sources and administering them on their own. This casts suspicion on the development of drug resistance in the area. Similar findings were reported by Seyoum et al. (2013) at Gojeb and Baro-Akobo River Basins. 


\section{Conclusions}

The results from the study demonstrated the presence of trypanosomosis as the major health problem of livestock in the settlement schemes. The most widely distributed and dominant species of trypanosome was $T$. congolense. Four more common and important tsetse flies species were identified. A significant reduction in the level of PCV was observed associated with the disease. Farmers are well aware of the problem, means of transmission, and the different control methods. The problem can be solved by integrating tsetse control with other trypanosomosis control options like the use of effective drugs for the treatment of the diseases. Continuous community awareness creation should be done about drug resistance and the use of veterinary services as appropriate sources and administration of the drugs.

\section{References}

'Abebe, G, and Jobre, Y., 1996. Trypanosomosis a threat to cattle production in Ethiopia. Revue Méd. Vét., 147, 897-902.

Abebe, G., 2005. Trypanosomosis in Ethiopia. Ethiop. J. Biomed. Sci., 4(1), 75-121.

Afework, Y., Clausen, P. H., Abebe, G., Tilahun, G. and Mehlitz, D., 2000. Multiple drugs resistant Trypanosoma congolense populations in Murray village cattle of Metekel District North West Ethiopia. Act. Trop., 76, 231-238.

Bekele, J., Asmare, K., Abebe, G., Ayelet, G. and Gelay, E., 2010. Evaluation of Delthametrine Application in the control of tsetse and trypanosomosis in Southern Rift Valley of Ethiopia. Vet. Parasitol., 168(3-4), 177-184.

Bitew, M., Amedie, Y., Abebe, A. and Tolesa, T., 2011. Prevalence of bovine trypanosomosis in selected areas of Jabi Tehenan district, West Gojam of Amhara regional State, North Western Ethiopia. Afr. J. Agric. Res., 6, 1-5.

Biyazen, H., Duguma, R. and Assaye, M., 2014. Trypanosomosis, Its risk factors and anaemia on cattle populations of Dale Wabara district of Kellem, West Wellega Zone, Western Ethiopia. J. Vet. Med., Volume 2014, Article ID 374191, https://doi. org/10.1155/2014/374191.

Brightwell, R., Dansfield, R.D., Korku, C.A., Golder, T. K., Tarima, S.A. and Magnai, D., 1997. A new trap for Glossina pallidipes. Trop. Pest. Manag., 33, 151-159.

Broun, D.M., Reid, R.S., Rogers, D.J., Shnow, W.F., Wint, G.R.W., 2001. Environmental change and the autonomous control of tsetse and trypanosomosis in Sub-Saha- 
ran Africa: case histories from Ethiopia, Gambia, Kenya, Nigeria, and Zimbabwe, Environmental Research Group, Oxford Limited, Oxford, UK. Pp. 9-24.

Cherenet, T., Sani, R.A., Speybroeck, N., Panandam, J.M., Nadzr,S., Van den Bossche, P., 2006. A comparative longitudinal study of bovine trypanosomiasis in tsetse-free and tsetse-infested zones of the Amhara Region, northwest Ethiopia. Vet. Parasitol., 140, 251-258.

Dagnachew, S., Sangwan, A.K., Abebe, G. 2005. Epidemiology of bovine trypanosomosis in the Abay (Blue Nile) Basin Areas of Northwest Ethiopia. Revue Élev. Méd. vét. Pays trop., 58 (3), 151-157

Drees, B.M., and Jackman, J.A., 1998. Field guide to common Texas insects. Taylor Trade Publishing. Pp 750.

Fimmen, H.O., Mehlitz, D., Horchoner, F., Korbo, E., 1992. Colostral antibodies and Trypanosoma congolense infection in calves, trypanotolerance research, and application. GTZ, No.116, Germany. Pp. 173-187.

Ford, J., Makin, M. J. and Grimle, R. J., 1976. Trypanosomosis control program for Ethiopia. Ministry of Overseas Development of Great Britain. Pp. 1-30.

Gechere, G., Terefe, G. and Belihu, K., 2012. Impact of tsetse and trypanosomiasis control on cattle herd composition and calf growth and mortality at Arbaminch District, Southern Rift Valley, Ethiopia. Trop. Anim. Health. Prod., 44(7), 1745-50

IAEA, 2004. Workshop on the strategic planning of area-wide tsetse and trypanosomiasis control In West Africa, May, 21-4, 2001. Ouagadougou, Burkina-Faso. Pp. 1-11

KWZRADO (Kellem Wollega Zone Rural and Agricultural Development Office), 2010. Annual report of Zonal Agricultural and Development activities, Kellem Wollega, Western Oromia, Ethiopia.

Langridge, W.P., 1976. A tsetse and trypanosomosis survey of Ethiopia. Ministry of Overseas Development, UK and Ministry of Agriculture of Ethiopia. Pp,1-40.

Leak, S.G.A., 1999. Tsetse Biology and Ecology: their role in the epidemiology and control Trypanosomosis. CABI Publishing in association with the ILRI. Pp. 152-210.

Leak, S.G.A., Woundyalew, M., Authie, E., D'Iteren, G.D.M., Peregrine, A.S., Rowlands, G.J., and Trail, J.C.M., 1993. Tsetse challenge and its relationship to Trypanosomosis prevalence in Cattle. Acta. Trop., 53, 121-134.

Luckins, A.G. 1992. Trypanosomiasis in small ruminants. A major constraint to livestock production. Br. Vet. J., 148, 471-473.

MacLennan, K.J.R., 1970. Tsetse transmitted trypanosomosis in relation to the rural ecology. World Animal. Rev., 36, 2-22. 
Ministry of Agriculture (MOA), 1995. Ruminant Livestock Development Strategy (RLDS). Ministry of Agriculture (MOA), Addis Ababa, Ethiopia, p. 113.

Ministry of Agriculture and Rural Development of the Government of Ethiopia (MoARD), 2004. Tsetse and trypanosomiasis prevention and control strategies. Amharic version. October 2004 (Tikimt 1997 Eth. Cal.). Paper presented on Farming In Tsetse Controlled Areas (FITCA), Ethiopia. Final Workshop, December 27-28, 2004. Adama, Ethiopia. Unpublished Workshop Proceedings.

Misganaw, T., 2006. Study on bovine trypanosomosis and tsetse fly in Quara settlement Area of North Gondor Zone, Amhara National Regional State. DVM thesis, Addis Ababa University Faculty of Veterinary Medicine, Debre-Zeit, Ethiopia

Mohamed-Ahmed, M. M., Ahmed, A. I. and Ishag, A., 1989. Trypanosome infection rate of Glossina morsitans submorsitans in Bahrel Arab, South Darfur Province, Sudan. Trop. Anim. Health. Prod., 21 (4), 239-244.

Msangi, S., 1999. Distribution, density and infection rate of tsetse in selected site of Southern Rift valley of Ethiopia. MSc thesis, Addis Ababa University, Faculty of Veterinary Medicine, Debre-Zeit, Ethiopia.

Murray, M., Trail, J. C., Turner, D. A. and Wissocq, Y., 1983. Livestock productivity and Trypanosomosis network manual, ILCA, Addis Ababa. p. 127.

Murray, P.K., Murray, M., Wallace, M. Morrison, W.I. \& McIntyre, W.I.M., 1977. Trypanosomiasis in N'Dama and Zebu cattle. I. An experimental investigation of susceptibility to Trypanosoma brucei, T. congolense and mixed infections In International Scientific Council for Trypanosomiasis Research and Control 15th meeting. The Gambia, OAU/STRC Publication No. 110, Pp. 470-481.

Muturi, K. S., 1999. Epidemiology of bovine trypanosomosis in selected sites of southern Rift Valley of Ethiopia. MSc Thesis, Addis Ababa and Free University of Berlin.

NTTICC, 1996. National Tsetse and Trypanosomosis investigation and control center. Annual report, Bedelle, Ethiopia.

Parkins J.JParkins J.J.P.H, 1989. Effects of gastrointestinal helminth parasites on ruminant nutrition. Nutr. Res. Rev., 2, 227-246.

PATTEC, 2001. Pan African Tsetse and Trypanosomiasis Eradication Commission (PATTEC) plan of action. June 2001.

Putt, H.N.S., Shaw, M.P.A., Woods, J.A., Tylor, L., James, D.A., 1988. Veterinary Epidemiology and Economics in Africa. A Manual for Use in the Design and Appraisal of Livestock Health Policy ILCA Manual No. 3, Pp. 30-39.

Rowlands G.J, Leak, S.G., Peregrine, A.S., Nagda, S.M., Mulatu, W., d'Ieteren. G.D., 2001. The incidence of new and the prevalence and persistence of recurrent try- 
panosome infections in cattle in southwest Ethiopia exposed to a high challenge with drug-resistant parasites. Acta Trop., 79(2), 149-163.

Rowlands, G.J., Mulatu, W., Nagda, S. M., Dalon, R.B., D’Ieteren, G. D. M., 1995. Genetic Variation in Pack red cell volume and frequency of aparasitaemic in East Africa Zebu cattle exposed to drug-resistant typanosomes Livest. Prod. Sci., 43, $75-84$.

Rowlands, G.J., Mulatu, W., Authie, E., D’Ieren, G. D., Leak, S. G., Nagda, S. M. and Peregrine, A. S., 1993. Epidemiology of bovine trypanosomosis in the Ghibe Valley, South West Ethiopia.2 Associated with variations in trypanosome prevalence, in the incidence of new infections and prevalence of recurrent infections. Acta Trop., $53(2), 135-150$

Seifert, H.S.H., 1996. Trypanosomosis In: Tropical Animal health. 2nd ed. Kluwer Academic Publishers, Dodrech, N.L. Pp. 15-168.

Senbata, T. 2010. Prevalence of cattle Anemia, Trypanosomosis, and Trypanocidal Drug Resistance and Apparent tsetse fly density in Western Oromia, DVM Thesis Addis Ababa University School of Veterinary Medicine, Debre-Zeit, Ethiopia.

Seyoum, Z., Terefe, G. and Ashenafi, H., 2013. Farmers' perception of impacts of bovine trypanosomosis and tsetse fly in selected districts in Baro-Akobo and Gojeb river basins, Southwestern Ethiopia. BMC Vet. Res., 9, 214. https://doi.org/10.1186/17466148-9-214

Sinshaw, A., Abebe, G., Desquesnes, M., Yoni, W., 2006. Biting flies and Trypanosoma vivax infection in three highland districts bordering Lake Tana, Ethiopia. Vet. Parasitol., 142, 35-46.

Swallow, B.M., 2000. Impacts of Trypanosomosis on African Agriculture. PAAT Technical and Scientific Series 2, FAO, Rome. Pp 52.

Tadesse, A. and Tsegaye, B., 2010. Bovine trypanosomosis and its vector in two districts of Bench Maji zone, South Western Ethiopia. Trop. Anim. Health. Prod., 42, 1757 1762.

Terefa, W., 2008. Studies on bovine trypanosomosis and therapeutic efficacy of selected trypanocidal drug in Birbir valley of Gawo Dale district in West Oromia. MSc thesis, Addis Ababa University Faculty of Veterinary Medicine, Debre Zeit, Ethiopia.

Tewelde, T., 2001. Study of the occurrence of drug-resistant trypanosome in cattle in the farming in tse tse controlled area (FITCA) Project in West Ethiopia. MSc. Thesis Addis Ababa University Faculty of Veterinary Medicine, Debre-Zeit, Ethiopia.

Thrusfield, M. 2005. Veterinary epidemiology. $3^{\text {rd }}$ ed. Edinburgh, UK: Blackwell Science Ltd. Pp. 182-189. 
Toma, B., Dufour, B., Sanaa, M., Benet, J.-J., Ellis, P., Moutou, F. and Louza, A., 1999. Applied veterinary epidemiology and control of disease in populations, editors. AEEMA, translated by Alexandra Shaw, Pp. 87-122.

Torr, S.J. 1995. Responses of tsetse flies (Diptera: Glossinidae) to natural and synthetic ox Odours. Entomol. Res., 85, 157-166.

Torr, S.J. and Mangwiro, T. N., 2000. Interactions between cattle and biting flies: effects on the feeding rate of tsetse. Med. Vet. Entomol., 14(4), 400-409.

Torr, S.J., Mangwiro, T.N.C. and Hall, D.R., 2006. The effects of host physiology on the attraction of tsetse (Diptera: Glossinidae) and Stomoxys (Diptera: Muscidae) to cattle. Bull. Entomol. Res., 96(1), 71-84.

Van den Bossche, P. Shumba, W., Makhabera, P., 2000. The epidemiology and distribution of bovine prevalence of trypanosomosis in Malawi. Vet. Parasitol., 88(3-4), 163-176.

Walle, R. and Shearer, D., 1997. Veterinary Entomology Arthropod Ectoparasites of Veterinary Importance. London, Champ man and Hall. Pp. 141-19 